\title{
Strategi Pembelajaran di Taman Kanak-kanak (TK) pada Era Pandemi Covid-19
}

\author{
James Anderson Lola \\ Institut Agama Kristen Negeri Toraja \\ jnlola86@gmail.com
}

\begin{abstract}
Covid-19 which has spread to almost all over the world, including in Indonesia, has brought many changes, and one of the sectors which have the most changes is education, because as an effect of the Covid-19, learning must be done remotely or distance Learning (PJJ), and also must be done in early childhood in Kindergarten (TK). Learning in kindergarten that is oriented towards the development of the child as an individual through the Developmentally Approach Practice (DAP) learning strategy which emphasizes the interaction between teacher and child, and the child and his / her environment must begin to adjust to a pandemic situation so that children's development can take place holistically.
\end{abstract}

Keywords: Distance Learning (PJJ), Kindergarden (TK), Strategy of Learning.

Abstrak: Pandemi Covid-19 yang menyebar ke hampir seluruh dunia termasuk di Indonesia, telah membawa begitu banyak perubahan, dan salah satu sektor yang paling banyak mengalami perubahan adalah dunia pendidikan, karena akibat pandemi Covid-19, pembelajaran harus dilakukan jarak jauh (PJJ) termasuk juga pembelajaran pada anak usia dini yang berada di Taman Kanakkanak (TK). Pembelajaran di TK yang berorientasi pada perkembangan anak sebagai sebuah individu melalui strategi pembelajaran Developmentally Approach Practice (DAP) yang begitu menekankan interaksi antara guru dan anak, dan anak dengan lingkungannya harus mulai menyesuaikan diri dengan situasi pandemi, agar perkembangan anak dapat berlangsung secara holistik. Salah satu strategi yang bisa digunakan adalah penggunaan media yang sangat popular di kalangan anak usia dini yaitu menggunakan video yang di desain seperti yang ada di Youtube.

Kata kunci: Pembelajaran Jarak Jauh (PJJ), Strategi Pembelajaran, Taman Kanakkanak (TK).

\section{Pendahuluan}

Anak-anak adalah generasi penerus dari suatu bangsa, oleh karena itu sejak usia dini, anak-anak sudah sepatutnya dipersiapkan untuk menguasai kemampuan dan 
keterampilan yang bersifat strategis yang dibutuhkan sebagai prasayarat yang dapat digunakan untuk mencerahkan masa depan sebuah bangsa.

Taman Kanak-kanak (TK) merupakan bentuk pendidikan prasekolah yang terdapat di jalur pendidikan anak usia dini (UU Sisdiknas no.20 tahun 2003 pasal 28) yang dalam fungsi dan tugasnya adalah untuk mempersiapkan anak dengan memperkenalkan berbagai pengetahuan, sikap/perilaku, keterampilan dan kemampuan intelektual agar dapat melakukan adaptasi dengan kegiatan belajar yang sesungguhnya di Sekolah Dasar (SD).

Taman Kanak-kanak (TK) merupakan lembaga pendidikan prasekolah yang bermaksud membina tumbuh dan kembang anak di bidang jasmani dan rohani. Pendidikan ini diberikan pada anak yang berada diusia 4 sampai 6 tahun. Pendidikan di TK sendiri biasanya dibagi menjadi dua kelompok yang disesuaikan dengan tingkat perbedaan usia yakni 4-5 tahun dalam kelompok A (atau biasa disebut TK A) dan usia 56 tahun dan disebut kelompok B (TK B).

Pendidikan di TK adalah wahana yang penting untuk pertumbuhan dan perkembangan anak, kesalahan dalam proses ini akan berdampak pada perkembangan anak dan tentu saja akan membawa kerugian bagi anak tersebut. Singgih Gunarsa menjelaskan pentingnya pendidikan anak pada usia prasekolah sebagai persiapan pembentukan karakter yang melaluinya emosi dan kepribadian anak dibentuk, serta menanamkan kepercayaan berinteraksi dengan orang lain. ${ }^{1}$ Hal ini berlandaskan pemahaman bahwa pada usia pra sekolah ini, anak-anak berada pada masa dimana mereka siap untuk maju dan bertumbuh, di masa ini mereka akan berusaha belajar keterampilan baru dan juga menggabungkan keterampilan-keterampilan yang mereka dapatkan melalui interaksi langsung dengan lingkungannya. ${ }^{2}$

Pembelajaran pada anak-anak di TK adalah sesuatu yang pada hakikatnya adalah sangat kompleks, karena pada usia ini anak tidak hanya belajar untuk menyerap informasi dan pengetahuan semata dari guru, melainkan karena anak juga belajar melalui interaksi dengan lingkungan sosialnya. Selain itu juga, belajar selalu melibatkan proses kognitif dan perubahan di mana anak akan belajar untuk menerapkan hasil pembelajarannya pada kehidupan sehari-hari melalui pengalaman dan latihan dalam tindakan nyata semakin membuat proses pembelajaran menjadi sesuatu yang kompleks.

Anak pada usia dini (0 - 8 tahun) pada dasarnya memiliki kemampuan belajar yang cukup cepat. Terutama pada masa usia 1-5 tahun, pada usia 1-5 tahun ini, anak memiliki keinginan yang kuat untuk belajar segala sesuatu dari apa yang dilihat dan didengar olehnya, ini secara tidak langsung berdampak pada aspek psikomotorik anak, 1991),26.

${ }^{1}$ Singgih D. Gunarsa, Psikologi Perkembangan Anak Dan Remaja (Jakarta: BPK Gunung Mulia,

${ }^{2}$ Carrol Seefeldt \& Nita Barbour, Early Childhood Education an Introduction, Fourth Edition (New Jersey: Merril of Pratince Hall, 1998), 11. 
di mana mereka menjadi lebih aktif dan eksploratif. Anak belajar dengan menggunakan seluruh komponen dalam dirinya terutama seluruh panca inderanya. ${ }^{3}$

Pada hakikatnya, fungsi dari TK adalah untuk membantu memungkinkan anakanak mengembangkan kemampuan-kemampuan mendengar, bercakap-cakap dan bertanya, melatih anak untuk menyukai buku, melatih mereka untuk bersosialisasi dengan teman sebayanya (berkawan) dan melatih mereka untuk menyesuaikan diri dengan lingkungan dalam situasi alamiah yang menyenangkan. Dengan kata lain, porsi yang lebih banyak ada di TK adalah porsi untuk bermain ketimbang porsi untuk belajar. Meskipun demikian, dalam pengelolaan dan proses pembelajaran di TK tetap merupakan sesuatu yang harus diperhatikan mengingat bahwa pada periode ini, anakanak akan dipersiapkan untuk memasuki Sekolah Dasar.

Kemampuan utama yang diprioritaskan dalam pendidikan di TK sesuai dengan Peraturan Pemerintah no.18 tahun 2018 tentang penyediaan layanan pendidikan anak usia dini ialah pendidikan anak usia dini harus dipahami sebagai suatu upaya pembinaan yang ditujukan kepada anak sejak lahir sampai dengan usia 6 (enam) tahun yang dilakukan untuk merangsang tumbuh kembang anak baik jasmani dan rohani sebelum melanjutkan ke pendidikan lebih lanjut. Pendidikan di TK lebih menekankan pengembangan diri anak daripada baca dan tulis dan hitung.

Anak adalah individu, itu berarti bahwa perkembangan seorang anak adalah suatu proses yang sifatnya menyeluruh (holistik) dan berbeda dari satu anak kepada anak yang lainnya, maksudnya adalah bahwa masing-masing anak berkembang dengan caracara tertentu dan berbeda satu dengan yang lainnya. Pada hakikatnya perkembangan seorang anak adalah perkembangan yang penuh dengan kompleksitas, di mana setiap unsur dalam diri anak saling terpengaruh satu dengan yang lain. ${ }^{4}$

Selain karena proses perkembangan yang berbeda antar setiap individu dan memiliki kompleksitas tersendiri, proses pendidikan di TK yang berbeda dengan pola pendidikan Sekolah pada umumnya semakin menjelaskan bahwa dibutuhkan strategi yang tepat untuk melatih dan mengembangkan jasmani dan rohani seorang anak, yaitu strategi pengembangan yang sesuai dengan karakteristik anak. Strategi yang digunakan harus benar-benar sesuai dengan kebutuhan dan perkembangan anak, baik intelektual, mental maupun sosial anak.

Selain itu juga, fakta mengenai pandemi covid-19 yang melanda seluruh dunia termasuk Indonesia dari sejak awal tahun 2020 semakin membuat proses pendidikan pada anak usia dini mendapatkan tantangan yang sama sekali baru. Salah satu efek dari pandemi adalah pelarangan proses pembelajaran tatap muka dan diganti dengan proses daring (Pembelajaran Jarak jauh), dan fakta ini membuat proses pembelajaran terutama pada anak usia TK, menjadi sangat tidak efektif.

\footnotetext{
${ }^{3}$ Akbar Reni Hawari, Psikologi Perkembangan Anak (Jakarta: Grasindo, 2001), 21. ${ }^{4}$ Muhibbin Syah, Psikologi Belajar (Jakarta: Raja Grafindo Persada, 2003),151.
} 
Ryan Dwi Puspita, Dinar Nurinten, Heni Nafiqoh dan Mubiar Agustin, dalam tulisan mereka di jurnal obsesi secara jelas memaparkan begitu banyak kesulitan yang timbul akibat pandemi covid-19 terhadap pendidikan anak usia dini, salah satu dari kesulitan yang disebabkan oleh pembelajaran jarak jauh adalah kesulitan untuk menciptakan situasi pembelajaran yang efektif, terutama sulitnya menciptakan komunikasi dalam kegiatan pembelajaran anak karena adanya jarak antara anak dan guru, bahkan sekalipun jika ada interaksi secara online, proses komunikasi tidak berlangsung optimal. Fakta ini memperlihatkan bahwa pandemi Covid-19 telah membawa kesulitan tersendiri bagi pendidikan anak di TK, padahal tatap muka dan terutama kontak fisik dalam kegiatan pembelajaran di PAUD adalah salah satu yang bagian dari proses pembelajaran dalam membantu anak didik mencapai kesuksesan dalam belajar. ${ }^{5}$ Lebih lanjut dalam penelitian ini, didapati bahwa ada empat kategori penghambat dari pembelajaran anak usia dini di era pandemi Covid-19 yaitu yaitu kendala komunikasi, metode pembelajaran, materi dan biaya serta penggunaan teknologi. ${ }^{6}$

Berdasarkan pada fakta-fakta di atas, pemilihan strategi yang tepat menjadi sesuatu yang sangat penting dalam proses pembelajaran pada anak usia dini. Oleh karena itu, artikel ini akan berupaya untuk mengkaji strategi pembelajaran anak TK di era pandemi covid-19.

\section{Metode Penelitian}

Penelitian dalam artikel ini menggunakan pendekatan penelitian kualitatif dengan model penelitian kepustakaan yaitu berusaha mencari sumber-sumber yang memiliki kaitan dengan pembahasan pada topik ini, selanjutnya menganalisisnya secara cermat guna mendapatkan solusi bagi persoalan yang sedang dibahas. Metode penulisan yang dipakai adalah metode deskriptif analisis. Dikatakan deskriptif karena penulis menggambarkan secara sistematis masalah yang diselidiki dan kemudian melakukan analisis terhadap persoalan tersebut.

\section{Hasil dan Pembahasan}

\section{Karakteristik Anak TK}

Anak TK pada dasarnya adalah anak yang berusia 4-6 tahun dan mereka dikategorikan dalam kelompok prasekolah. Pada masa ini seorang anak sudah dapat memahami konsep seperti ruang dan waktu. ${ }^{7}$ Beberapa aspek terkait:

${ }^{5}$ Mubiar Agustin Ryan Dwi Puspita, Dinar Nurinten, Heni Nafiqoh, “Tipikal Kendala Guru PAUD Dalam Mengajar Pada Masa Pandemi Covid 19 Dan Implikasinya," Jurnal Obsesi : Jurnal Pendidikan Anak Usia Dini 5, no. 1 (2020): 334-45, https://doi.org/10.31004/obsesi.v5i1.598.

6 ibid 210.

${ }^{7}$ Diane E. Papalia \& Sally Wndoks Old, Human Development (New York: Mc.GrawHill Inc, 1995), 
Aspek Kognitif

Kognitif erat kaitannya dengan pikiran, memori, nalar, intelektual, dan kemampuan berhitung. Menurut Jean Piaget seperti dikutip Singgih Gunarsa, perkembangan kognitif dipengaruhi beberapa aspek, antara lain:(1). Kematangan, yang merupakan pengembangan terutama pada susunan syaraf. (2). Pengalaman, yaitu hubungan timbal balik antara organisme dengan lingkungan dan dunianya. (3). Transmisi sosial, yaitu pengaruh-pengaruh yang diperoleh dalam hubungan dan interaksinya dengan lingkungan sosial. (4). Ekuilibrasi, yaitu kemampuan yang dimiliki oleh seorang anak untuk bisa mengatur dalam dirinya sendiri agar anak dapat menyesuaikan diri dengan lingkungan sekitarnya. ${ }^{8}$

Dalam perkembangan kognitif ada dua fakta yang menonjol yaitu (1) semua manusia mempunyai unsur-unsur kesamaan di dalam pola perkembangan dan (2) di dalam pola yang bersifat umum dari apa yang membentuk warisan manusia secara biologis dan sosial setiap individu mempunyai kecenderungan yang berbeda. ${ }^{9}$ Harsanto dalam bukunya mencoba membagi perkembangan kognitif ini dalam enam kategori dengan penekanan dan implementasi pembelajaran yang berbeda. Keenam kategori itu ialah pengetahuan, pemahaman, aplikasi, analisis, sintesis, evaluasi. 10

Pada periode TK, perkembangan kognitif seorang anak dapat terlihat pada perubahan-perubahan dalam kemampuan dan pola berpikir, kemahiran berbahasa, dan cara individu memperoleh pengetahuan dari lingkungannya. Pada periode ini, perkembangan kognitif anak dapat terlihat secara langsung pada minatnya yang tinggi terhadap huruf-huruf dan angka-angka, ketertarikan yang sangat tinggi kepada alam, dapat mengingat sesuatu dengan baik, dan memiliki kosakata di antara 5000 sampai 6000 kata. $^{11}$

Dalam periode ini, tahap kognitif seorang anak berada pada tahap pengetahuan dalam pembagian yang dijelaskan oleh Harsanto, tahap ini merupakan tahap pengenalan simbolik dan anak belum dapat berpikir secara logis, pada tahap ini penggunaan kemampuan kognitif anak sebatas hanya pada penggambaran apa yang ada dalam pikirannya tentang suatu peristiwa.

Selain itu juga, pada periode ini, perkembangan kognitif anak dapat terlihat juga melalui kemampuan dia untuk menggambar segi empat, segi tiga dan kemampuan untuk menghitung jari-jarinya, dapat mengingat dan menyebut nama hari dalam satu minggu serta dapat membedakan bentuk dan besar sebuah benda.

\footnotetext{
${ }^{8}$ Gunarsa, Psikologi Perkembangan Anak Dan Remaja, 141.

${ }^{9}$ H. Sunarto, Perkembangan Peserta Didik (Jakarta: Rineka Cipta, 2006), 6.

10 R. Harsanto, Pengelolaan Kelas Yang Dinamis: Paradigma Baru Pembelajaran Menuju Kompetensi Siswa. (Yogyakarta: Kanisius, 2007), 95-98.

${ }^{11}$ Carrol Seefeldt \& Nita Barbour, Early Childhood Education an Introduction, Fourth Edition (New Jersey: Merril of Pratince Hall, 1998), 40-52.
} 


\section{Aspek Afektif}

Afektif memiliki cakupan yang berbeda dengan kognitif, afektif pada hakikatnya lebih berhubungan dengan kejiwaan dan berkaitan dengan emosi serta kepribadian individu dan juga berkaitan dengan cara anak untuk berkomunikasi dengan orang lain yang di sekitarnya. Contoh dari proses-proses, psikososial antara lain: pergaulan anak dengan temannya, aktualisasi anak dengan perilaku-perilaku sehari-harinya. Pada periode ini, anak mencoba untuk mencari pengalaman kehidupan di luar rumah dengan bersosialisasi dan berinteraksi dengan teman sebayanya dan memiliki rasa senang untuk bermain dengan temannya. ${ }^{12}$

Periode TK, perkembangan afektif seorang anak terlihat dengan jelas dalam perkembangan emosi, di mana anak memiliki tahapan emosi yang tinggi melalui rasa simpati dan menaruh minat pada kegiatan-kegiatan yang dilakukan oleh orang dewasa termasuk membantu pekerjaaan atau kegiatan rumah yang sederhana.

\section{Aspek Psikomotorik}

Perkembangan anak pada usia TK ini dapat terlihat secara jelas dalam perubahan tinggi dan berat badan anak, dan juga melalui perilaku anak yang terus menerus memperbaiki keterampilan gerak motorik kasar dan halusnya. ${ }^{13}$ Anak pada tahap ini dapat melompat, melangkah, berlari dan melakukan gerak-gerakan sederhana dari olahraga misalnya bersepeda, berenang dan senam. Sedangkan perkembangan motorik halusnya sudah mulai terlihat melalui kemampuan untuk menulis.

Melalui pendekatan kepada perkembangan anak di usia TK ini, dapat disimpulkan bahwa untuk membantu perkembangan anak agar kognitif, afektif dan psikomotorik dapat tumbuh dengan baik adalah bahwa anak membutuhkan interaksi yang intens baik itu dengan guru TK yang akan membimbingnya atau dengan teman-teman sebayanya.

Interaksi sosial menjadi faktor penting bagi anak untuk melatih setiap aspek dalam perkembangannya. Anak TK belajar melalui seluruh panca inderanya, sehingga kebutuhan yang paling mendasar dari anak pada usia TK adalah situasi yang mendukung untuk dirinya mampu menggunakan seluruh panca inderanya dengan maksimal demi pertumbuhan dan perkembangannya.

\section{Strategi Belajar Mengajar di TK}

Strategi secara sederhana dapat dimengerti sebagai panduan yang dapat dijadikan sebagai acuan untuk bertindak demi mencapai tujuan. Sehubungan dengan proses pembelajaran, strategi dapat dimengerti sebagai interaksi antara guru-anak didik dalam

\footnotetext{
12 ibid, 40-52.

13 Ibid.
} 
kegiatan belajar-mengajar untuk mencapai tujuan yang telah ditentukan. ${ }^{14}$ Berdasarkan pengertian ini, maka penggunaan strategi belajar mengajar yang tepat akan sangat memengaruhi hasil dari proses pembelajaran.

Menurut Gerlach, Veron S dan Ehg Donal P, strategi belajar merupakan pemilihan jenis latihan tertentu yang dipikirkan akan cocok dengan tujuan yang akan dicapai. ${ }^{15}$ Maksudnya adalah strategi adalah sesuatu yang lebih luas dari sekedar pemilihan metode dan teknik mengajar, strategi lebih merujuk kepada segala hal yang berkaitan dengan proses pembelajaran termasuk di dalamnya media pembelajaran dan pola komunikasi yang tepat.

Dari dua penjelasan ini, maka dapat disimpulkan bahwa strategi belajar mengajar adalah sebuah pendekatan pembelajaran yang mengutamakan pemilihan metode dan teknik mengajar serta media pembelajaran yang disesuaikan dengan materi pembelajaran sesuai dengan criteria dari peserta didik yang dihadapi.

Dengan demikian, maka dalam kegiatan pembelajaran, terdapat setidaknya empat strategi dasar yaitu: (1) Identifikasi serta penetapan kualifikasi perubahan tingkah laku dan pola-pola kepribadian dari seorag murid. (2) Pemilihan sistem pendekatan belajar mengajar yang sesuai dengan tujuan yang telah ditetapkan dan karakteristik peserta didik. (3) Penggunaan langkah-langkah, pendekatan metode dan pemilihan teknik belajar mengajar yang disesuaikan dengan penggunaan alat-alat belajar yang tepat. (4) Penetapan kriteria standar untuk menilai suatu keberhasilan sehingga dapat dijadikan sebagai pedoman untuk melakukan monitoring dan evaluasi kegiatan belajar mengajar. ${ }^{16}$

Mengingat bahwa pendidikan anak usia dini adalah sesuatu yang sangat penting, maka strategi pendidikan yang tepat adalah pola pendidikan yang menerapkan konsep Developmentally Appropriate Practice (DAP) yang mana hal ini sesuai dengan peraturan pemerintah yang menjelaskan mengenai fungsi dan tugas pendidikan anak usia dini dalam Peraturan Pemerintah no.18 tahun 2018, yakni (1) Pembelajaran dalam PAUD dilaksanakan dengan menggunakan pendekatan berpusat pada anak dalam konteks bermain sesuai dengan tingkat pencapaian perkembangan anak. (2) Pembelajaran dalam PAUD sebagaimana dimaksud pada ayat (1) bertujuan untuk mengoptimalkan seluruh potensi perkembangan anak dengan tidak mengutamakan kemampuan baca, tulis, dan hitung. (3) Pembelajaran dalam PAUD tidak menggunakan pendekatan skolastik yang memaksa peserta didik secara fisik maupun psikis untuk memiliki kemampuan membaca, menulis, dan berhitung.

5.

${ }^{14}$ Syaiful Bahri Djamarah dan Aswan Zain, Strategi Belajar Mengajar (Jakarta: Rineka Cipta, 1997),

${ }^{15}$ Ehg. Donal P Gerlach, Veron S, Teaching and Media: A System Approach (New Jersey: Prentice Hall, 1980), 32.

16Zain, Strategi Belajar Mengajar, 5. 
Konsep DAP sendiri sebagaimana yang diungkapkan oleh Bredekamp berpijak pada dua kesesuaian yakni kesesuaian usia dan individu anak. Kesesuaian usia berkaitan dengan pertumbuhan dan perkembangan anak secara sekunsial yang sifatnya universal yakni perubahan yang terjadi pada aspek fisik, emosi, sosial maupun kognitif, sedangkan kesesuaian individu memiliki pengertian bahwa setiap anak memiliki karakteristik yang unik dalam berinteraksi dalam proses belajarnya. ${ }^{17}$

Penerapan dari konsep DAP dalam proses pembelajaran dapat ditemukan dalam tiga bentuk strategi belajar mengajar yakni, belajar dari pengalaman, pembelajaran bersifat terpadu dan belajar sambil bermain. Dalam proses belajar melalui pengalaman, anak dilatih kemampuan untuk mengembangkan konsep kognitif dari sebuah pengetahuan prosedural kepada pengetahuan konseptual atau dari pengetahuan kongkrit kepada pengetahuan abstrak. ${ }^{18}$

Pembelajaran terpadu menurut Halida seperti yang dikutip dari Trianto adalah sebuah konsep mengenai proses belajar mengajar yang mengorganisir program pendidikan (kurikulum) dengan tujuan untuk memberikan dampak dalam proses perencanaan, pelaksanaan dan tidakan monitoring dan evaluasi program pendidikan yang sesuai. ${ }^{19}$

Pembelajaran terpadu dimaksudkan sebagai sebuah sistem yang mengintegrasikan semua kurikulum, maka kurikulum yang disusun bagi anak usia dini di TK haruslah merupakan kurikulum yang disesuaikan dengan perkembangan dari anak tersebut. Menurut Bredecamp "Bukan anak yang harus disesuaikan dengan program tetapi program yang harus disesuaikan dengan anak". ${ }^{20}$ Dengan kata lain bahwa kurikulum untuk TK harus merupakan sebuah kurikulum yang dapat mengembangkan potensi seorang anak secara holistik, baik aspek kognitif, afektif maupun psikomotoriknya.

Halida dengan mengutip Aisyah menjelaskan bahwa karakteristik pembelajaran terpadu dapat dilihat dalam beberapa aspek, antara lain: Pertama, memberi pengalaman langsung kepada anak tentang obyek nyata untuk melatih panca inderanya. Kedua, melakukan kegiatan yang dapat melatih pemikiran anak. Ketiga, kegiatan yang dilakukan sebaiknya sesuai dengan minat anak. Keempat, membantu mengembangkan aspek pengetahuan dan keterampilan anak berdasarkan kegiatan yang dapat mereka lakukan. Kelima, mengadakan kegiatan yang dapat mengembangkan aspek kognitif, sosial, emosional, fisik afeksi, dan estetis, dan agama. Keenam, mengakomodir kebutuhan anak dalam aktivitas fisik interaksi, sosial, kemandirian, dan pengembangan

\footnotetext{
${ }^{17}$ Sue Bredekamp, Developmentally Appropriate Practice in Early Childhood Program Servings Chilhood from Birth Trough Age 8 (USA: NAEYC, 1986), 2.

18 Ibid.

${ }^{19}$ Halida, “Group Investigation Model (Pembelajaran Terpadu Anak Usia Dini)," Jurnal Pembelajaran Prospektif 1, no. 2 (2016): 1-8, https://jurnal.untan.ac.id/index.php/lp3m.

${ }^{20}$ Sue Bredekamp, Developmentally Appropriate Practice in Early Childhood Program Servings Chilhood from Birth Trough Age 8,
} 
harga diri secara positif. Tujuh, menggunakan kegiatan bermain sebagai wahana belajar. Delapan, menghargai perbedaan latar belakang pengalaman keluarga dari setiap anak. Sembilan, mengadakan kegiatan yang dapat melibatkan anggota keluarga dari anak. ${ }^{21}$

Implementasi ketiga dari pembelajaran konsep DAP adalah belajar sambil bermain. Menurut Horn, belajar sambil bermain adalah salah satu model pendekatan belajar yang sangat penting karena belajar sambil bermain memiliki dua karakteristik, yatu pertama, bermain adalah sesuatu yang mudah untuk disesuaikan oleh anak dan kedua karena bermain selalu melibatkan anak dalam mencari jalan keluar terhadap sebuah permasalahan yang dihadapinya menurut cara yang dipilih oleh anak tersebut. ${ }^{22}$

Salah satu fungsi penting bermain menurut Piaget seperti dikutip oleh Ade Holis ialah memberi kesempatan kepada anak untuk memahami keberadaan dirinya. Taman kanak-kanak harusnya menjadi tempat yang efektif bagi anak dalam belajar sambil bermain dan atau sebaliknya. Dengan demikian TK akan menjadi wadah pengembangan diri anak. ${ }^{23}$ Jadi, bermain dimaksudkan untuk melatih kemampuan anak secara kompeherensif, selain itu ada nilai lain yang tidak kalah pentingnya yaitu dapat mengatasi kecemasan atau ketegangan yang didapatkan oleh anak. Penyelenggaraan pendidikan TK yang menerapkan konsep DAP hendaknya dikembangkan untuk memberikan dasar bagi anak untuk dapat memiliki pengetahuan, keterampilan, perilaku dan sikap guna pertumbuhan dan perkembangannya di masa depan.

\section{Strategi Pembelajaran TK di Era Pandemi Covid-19}

Strategi pembelajaran DAP pada hakikatnya sebuah pendekatan pembelajaran yang efektif untuk dilakukan di TK. Namun di era pandemi Covid-19 telah terjadi perubahan tatanan dari kehidupan manusia, termasuk berdampak terhadap pendidikan di TK. Sejak era pandemi, pendidikan di Indonesia termasuk TK harus dilakukan melalui metode daring atau Pembelajaran Jarak Jauh (PJJ) yang diatur melalui Surat Edaran Menteri Pendidikan Nomor 4 Tahun 2020 tentang Pelaksanaan Pendidikan Dalam Masa Darurat Corona Virus Disease (Covid-19).

PJJ sendiri dipahami sebagai sebuah model pembelajaran yang menggunakan suatu media yang memungkinkan terjadinya interaksi antara pengajar dan pembelajar. Dalam PJJ antara pengajar dan pembelajar tidak bertatap muka secara langsung. ${ }^{24}$ Lebih lanjut Daryanto dan Karim menyatakan bahwa hakikat dari PJJ adalah penekanan pembelajaran pada peserta didik dan kepada proses belajar secara utuh sehingga PJJ

\footnotetext{
${ }^{21}$ Halida, “Group Investigation Model (Pembelajaran Terpadu Anak Usia Dini)."

22J. Et. Al. Van Horn, Play at Centre of the Curriculum (New York: Macmillan, 1993), 114.

${ }^{23}$ Ade Holis, "Belajar Melalui Bermain Untuk Pengembangan Kreativitas Dan Kognitif Anak Usia Dini," Jurnal Pendidikan Universitas Garut 09, no. 1 (2017), http://journal.uniga.ac.id/index.php/JP/article/download/84/86.

${ }^{24}$ Daryanto \& Syaiful Karim, Pembelajaran Abad 21 (Yogyakarta: Gava Media, 2017), 96.
} 
merupakan salah satu model pembelajaran yang sangat sesuai dengan abad-21.25 Ini berarti bahwa PJJ memiliki nilai yang luar biasa untuk kemajuan pendidikan.

PJJ sendiri adalah sebuah model pendidikan yang sudah sejak lama diatur dalam perundang-undangan Bangsa Indonesia bahkan sebelum era pandemi covid-19 terjadi di Indonesia yaitu sejak tahun 2012 melalui Permendikbud nomor 24 tahun 2012 dan ditegaskan kembali melalui Permendikbud no.109 tahun 2013.

Meski sudah diatur sejak 2012, nyatanya model pembelajaran jarak jauh ini belum sepenuhnya dilaksanakan di Indonesia sebelum era pandemi Covid-19 ini, sehingga ketika model pembelajaran ini dilakukan akibat dari pandemi covid-19 ini membuat banyak persoalan terutama bagi pendidikan di TK. Meminjam istilah yang digunakan oleh Mubir Agustin, dkk adalah terjadi "kekagetan budaya" bagi guru TK dan peserta didik $^{26}$, karena belum pernah sebelumnya PJJ dilakukan pada konteks TK mengingat karena PJJ memang dibuat untuk model pembelajaran orang dewasa ${ }^{27}$. Selain menimbulkan kekagetan budaya, pembelajaran secara daring atau PJJ ini juga menurut penelitian Mubir Agustin dkk, juga memperlihatkan bahwa PJJ sangatlah tidak efektif dilakukan kepada anak-anak TK mengingat karakteristik anak TK yang sangat membutuhkan interaksi yang intens antara anak yang sedang berkembang. ${ }^{28}$

Persoalan-persoalan teknis juga menjadi kendala dalam proses PJJ. Jaringan internet yang sering terganggu, ketidaksiapan orang tua dalam bekerjasama dengan guru untuk mendidik anak, dan persoalan-persoalan lainnya yang bisa saja menjadi masalah tersendiri dalam proses PJJ. Oleh karena itu untuk tetap menjalankan DAP dalam proses PJJ, maka pendekatan pembelajaran di era pandemi covid-19 ini harus dimodifikasi melalui proses pembelajaran yang mengutamakan penggunaan teknologi, salah satunya adalah dengan memanfaatkan layanan pendidikan yang disediakan pemerintah bagi anak melalau saluran televisi (TVRI) dan atau guru bisa membuat video yang berisi pengajaran mengingat bahwa anak-anak usia TK sangat menyukai untuk menonton video salah satu media yang paling banyak ditonton oleh anak adalah youtube. ${ }^{29}$

Selain itu melalui proses PJJ ini, guru dapat lebih aktif untuk menggunakan mediamedia yang variatif, misalnya mencari di internet atau applikasi game yang dapat membantu aspek perkembangan anak. Menurut Eko Suhendro dengan mengutip La Ode menjelaskan bahwa penggunaan media-media yang variatif dalam pembelajaran anak

25 Ibid, 97

${ }^{26}$ Ryan Dwi Puspita , Dinar Nurinten, Heni Nafiqoh, “Tipikal Kendala Guru PAUD dalam Mengajar Pada Masa Pandemi Covid 19 dan Implikasinya."

${ }^{27}$ Karim, Pembelajaran Abad 21, 97

28 ibid

29 Diah Ayu Patmaningrum Asaas Putra, "Pengaruh Youtube di Smartphone Terhadap Perkembangan Komunikasi Interpersonal Anak," Jurnal Penelitian Komunikas 21, no. 2 (2018): 159-72, https://doi.org/10.20422/jpk.v21i2.589. 
TK merupakan salah satu jalan keluar untuk menghasilkan pendidikan online yang ideal dan tentu saja dapat mengakomodasi kebutuhan belajar bagi para siswa untuk dapat mengembangkan potensi sesuai dengan tujuan pendidikan yang hendak dicapai. ${ }^{30}$

Dalam proses PJJ di rumah, guru dapat memberikan tugas lain yang bisa melatih aspek kognitif, afektif dan psikomotorik dan melatih diri anak untuk dapat berinteraksi dengan lingkungan sekitarnya yaitu dengan memberikan materi-materi pembelajaran yang merupakan kebiasaan anak di rumah, misalnya membantu orang tua untuk membersihkan rumah, merapikan mainannya sendiri, membantu untuk merapikan tempat tidur sendiri, melatih anak untuk terbiasa hidup bersih dan sehat melalui praktek rajin cuci tangan, mandi, gosok gigi, melatih anak untuk berbicara sopan, mengucapkan terima kasih, mengucapkan maaf bila salah, dan lain sebagainya.

Aktivitas seperti di atas dapat membantu perkembangan anak, juga meringankan beban orang tua dalam ikut berpartisipasi pada proses perkembangan anak. Dikatakan demikian karena banyak orang tua yang tidak terbiasa mengajar anak di rumah seringkali memarahi anak karena alasan-alasan yang sepele sehingga secara tidak langsung membawa dampak yang cukup buruk bagi perkembangan anak. ${ }^{31}$

Untuk melatih anak bersosialisasi dengan teman-teman sebayanya, maka guru dapat membentuk kelompok yang terdiri dari 3 sampai 4 orang anak. Kemudian guru dapat melakukan kunjungan ke rumah kelompok-kelompok yang telah ditentukan sebelumnya. Perkunjungan dilakukan dengan tetap memperhatikan protokol kesehatan.

Menurut Eko Suhendro, perkunjungan memiliki dampak positif yang besar bagi perkembangan anak dan juga bagi orang tua. Menurutnya ada nilai positif yang hendak ditanamankan sehubungan dengan proses pendidikan, antara lain memotivasi anak dalam belajar, maupun orang tua untuk memperhatikan pendidikan anak-anaknya. ${ }^{32}$

Meski di tengah persoalan pandemi yang memaksa proses pendidikan TK harus dilakukan melalui proses PJJ, tidak membuat proses pendidikan di TK menjadi terbengkalai atau gagal. Sebaliknya, dengan penggunaan strategi DAP yang disesuaikan dengan kondisi saat ini, diharapkan dapat membuat perkembangan anak dapat terlaksana secara holistik mengingat bahwa pendidikan pada periode ini sangat memiliki peranan yang penting untuk membantu anak mempersiapkan masa depannya.

\section{KESIMPULAN}

Strategi pembelajaran yang mendasarkan pembelajaran pada pendekatan kepada perkembangan anak (DAP) merupakan strategi pendidikan yang tepat. Strategi ini

${ }^{30}$ Eko Suhendro, "Strategi Pembelajaran Pendidikan Anak Usia Dini Di Masa Pandemi Covid-19," GOLDEN AGE Jurnal Ilmiah Tumbuh Kembang Anak Usia Dini 5, no. 3 (2020): 133-40, https://doi.org/DOI: https://doi.org/10.14421/jga.2020.53-05.

${ }^{31}$ Cipta Pramana, "Pembelajaran Pendidikan Anak Usia Dini (PAUD) Dimasa Pandemi Covid-19," Indonesian Journal of Early Childhood: Jurnal Dunia Anak Usia Dini 2, no. 2 (2020): 115-24, https://doi.org/10.35473/ijec.v2i2.557.

32Eko Suhendro, “Strategi Pembelajaran Pendidikan Anak Usia Dini Di Masa Pandemi Covid-19.” 
membantu perkembangan anak usia dini terutama yang sementara belajar di TK sebagai persiapan untuk anak meneruskan ke jenjang pendidikan selanjutnya.

Situasi pandemi Covid-19 yang membuat proses pendidikan harus dilangsungkan dalam kondisi jarak jauh untuk memutus rantai penyebaran virus corona memang pada awalnya telah membuat "kekagetan budaya" namun bukan berarti juga harus memaksa pendidikan di TK tidak dapat berjalan secara efektif. Melalui pendekatan-pendekatan pembelajaran DAP yang dikondisikan sesuai dengan keadaan pandemi ini pada kenyataannya telah memberikan peluang yang cukup besar bagi pengembangan pendidikan di TK.

Memang, masih ada beberapa hambatan berkaitan dengan proses PJJ bagi anak TK, namun dengan sinergitas antara pemerintah, lembaga pendidikan (TK) dan orang tua, maka diharapkan proses pendidikan di TK yang bertujuan untuk membantu anak berkembang dapat terlaksana dengan baik.

Salah satunya strategi yang dapat digunakan oleh guru adalah dengan penggunaan media terutama video, guru bisa membuat video yang dapat ditonton di youtube atau video offline yang didesain sedemikian rupa agar memiliki kemiripan dengan video lainnya di youtube mengingat bahwa anak pada usia TK ini sangat menyukai untuk menonton youtube. Selain video, guru juga dapat menggunakan pembelajaran bersifat kelompok kecil, di mana guru dapat mengunjungi anak-anak yang terbagi di dalam kelompok kecil tersebut untuk mengajar, memantau dan mengevaluasi perkembangan anak selama melakukan PJJ.

\section{Referensi}

Akbar Reni Hawari. Psikologi Perkembangan Anak. Jakarta: Grasindo, 2001.

Asaas Putra, Diah Ayu Patmaningrum. "Pengaruh Youtube di Smartphone Terhadap Perkembangan Komunikasi Interpersonal Anak." Jurnal Penelitian Komunikas 21, no. 2 (2018): 159-72. https://doi.org/10.20422/jpk.v21i2.589.

Carrol Seefeldt \& Nita Barbour. Early Childhood Education an Introduction, Fourth Edition. New Jersey: Merril of Pratince Hall, 1998.

Cipta Pramana. "Pembelajaran Pendidikan Anak Usia Dini (PAUD) di Masa Pandemi Covid-19." Indonesian Journal of Early Childhood: Jurnal Dunia Anak Usia Dini 2, no. 2 (2020): 115-24. https://doi.org/10.35473/ijec.v2i2.557.

Eko Suhendro. "Strategi Pembelajaran Pendidikan Anak Usia Dini di Masa Pandemi Covid-19." GOLDEN AGE Jurnal Ilmiah Tumbuh Kembang Anak Usia Dini 5, no. 3 (2020): 133-40. https://doi.org/DOI: https://doi.org/10.14421/jga.2020.53-05.

Gerlach, Veron S, Ehg. Donal P. Teaching and Media: A System Approach. New Jersey: Prentice Hall, 1980. 
Gunarsa, Singgih D. Psikologi Perkembangan Anak dan Remaja. Jakarta: BPK Gunung Mulia, 1991.

Halida. "Group Investigation Model (Pembelajaran Terpadu Anak Usia Dini)." Jurnal $\begin{array}{llllll}\text { Pembelajaran } & \text { Prospektif } & 1, & \text { no. } & 2 & \text { (2016): }\end{array}$ https://jurnal.untan.ac.id/index.php/lp3m.

Harsanto, R. Pengelolaan Kelas yang Dinamis: Paradigma Baru Pembelajaran Menuju Kompetensi Siswa. Yogyakarta: Kanisius, 2007.

Holis, Ade. "Belajar Melalui Bermain Untuk Pengembangan Kreativitas dan Kognitif Anak Usia Dini." Jurnal Pendidikan Universitas Garut 09, no. 1 (2017). http://journal.uniga.ac.id/index.php/JP/article/download/84/86.

J. Et. Al. Van Horn. Play at Centre of the Curriculum. New York: Macmillan, 1993.

Karim, Daryanto \& Syaiful. Pembelajaran Abad 21. Yogyakarta: Gava Media, 2017.

Old, Diane E. Papalia \& Sally Wndoks. Human Development. New York: Mc.GrawHill Inc, 1995.

Ryan Dwi Puspita, Dinar Nurinten, Heni Nafiqoh, Mubiar Agustin. “Tipikal Kendala Guru PAUD dalam Mengajar pada Masa Pandemi Covid 19 dan Implikasinya." Jurnal Obsesi: Jurnal Pendidikan Anak Usia Dini 5, no. 1 (2020): 334-45. https://doi.org/10.31004/obsesi.v5i1.598.

Sue Bredekamp. Developmentally Appropriate Practice in Early Childhood Program Servings Chilhood from Birth Trough Age 8. USA: NAEYC, 1986.

Sunarto, H. Perkembangan Peserta Didik. Jakarta: Rineka Cipta, 2006.

Syah, Muhibbin. Psikologi Belajar. Jakarta: Raja Grafindo Persada, 2003.

Zain, Syaiful Bahri Djamarah dan Aswan. Strategi Belajar Mengajar. Jakarta: Rineka Cipta, 1997. 